\section{Proposal for an administrative procedures manual with a biosafety approach after Covid- 19}

Propuesta de un manual de procedimientos administrativo con enfoque de bioseguridad tras el Covid-19

\section{Cristhian Gregorio Barreto Silva * Ángela María Pazmiño Montes * William Renán Meneses Pantoja * Edisson Javier Mera Silva *}

\section{ABSTRACT}

The present research seeks to create an organizational structure design for the Restaurant "Mi Galito", to implement sales and distribution strategies in order to contribute in the foundation of solid bases to be able to compete in the current market; due to the current conditions in which the business is found as a result of the pandemic by "Covid-19". Therefore, a descriptive, qualitative-quantitative research was developed with the use of methods in the theoretical order and techniques in the practical order such as interviews and surveys to the main actors involved. As a result, it was found that the business has a high acceptance rate of $90 \%$ for the taste of its dishes and with a $100 \%$ satisfaction regarding the service, for which the variety of flavors and its low prices are the qualities valued by external customers; also, it was known that the restaurant was not operational during the second quarter of 2020 due to the pandemic that represented a reduction in demand even in the process of reopening. Organizational change due to contingencies in the context makes it imperative to analyze the organizational structure of a business in order to adapt to current demands, obtain profits or survive in the market.

\footnotetext{
* Student of Business Administration at the Universidad Laica Eloy Alfaro de Manabí, Bahía de Caráquez extension, Email: el314099191@live.uleam.edu.ec; https://orcid.org/0000-0002-7650-2694
* Student of Business Administration at the Universidad Laica Eloy Alfaro de Manabí, Bahía de Caráquez extension, Email: el313603746@live.uleam.edu.ec; https://orcid.org/0000-0002-5474-1897

* Master in Tourism Marketing and Innovation E-mail:

* Student of Business Administration at the Universidad Laica Eloy Alfaro de Manabí, Bahía de Caráquez extension, Email: el3|3। I8802@live.uleam.edu.ec; https://orcid.org/0000-0002-6926-8246
}

\section{JOURNAL OF BUSINESS and entrepreneurial studies \\ ISSN: 2576-097|}

Atribución/Reconocimiento-NoCo mercial- Compartirlgual 4.0 Licencia Pública Internacional - CC

\section{BY-NC-SA 4.0}

https://creativecommons.org/licenses

/by-nc- sa/4.0/legalcode.es

Journal of Business and entrepreneurial January - March Vol. 6 - I - 2022

http://journalbusinesses.com/index.php/revista e-ISSN: 2576-097I

journalbusinessentrepreneurial@gmail.com Receipt: I4 March 202 I

Approval: 19 June 2021

Page 17- 26 
Keywords: Organizational structure, sales strategies, Covid-19 and market.

\section{RESUMEN}

En la presente investigación se busca crear un diseño de estructura organizacional para el Restaurante "Mi Galito", implementar estrategias de ventas y distribución con la finalidad de contribuir en la cimentación de bases sólidas para poder competir en el mercado actual; debido a las condiciones actuales en las que se encuentran el negocio a consecuencia de la pandemia por "Covid-19". Por tanto, se desarrolló una investigación descriptiva, cuali-cuantitativa con el uso de métodos en el orden teórico y técnicas en el orden práctico como entrevista y encuestas a los principales actores involucrados. Como resultado, se conoció que el negocio tiene una alta aceptación con $90 \%$ por el sabor de sus platos y con un $100 \%$ de satisfacción respecto al servicio, por lo cual la variedad de sabores y sus precios bajos son las cualidades valoradas de los clientes externos; también, se conoció que el restaurante no estuvo operativo durante el segundo trimestre del 2020 por la pandemia que representó una reducción de su demanda aún en el proceso de reapertura. El cambio organizacional debido a las contingencias en el contexto hace imperativo el análisis de la estructura organizacional de un negocio para adaptarse a las demandas actuales, obtener ganancias o sobrevivir en el mercado.

Palabras clave: Estructura organizacional, estrategias de ventas, Covid-19 y mercado.

\section{INTRODUCTION}

The present research is based on the designs of the organizational structures in the sales processes, which is based on the services provided by the restaurant Mi Galito for the realization of a study of the capabilities of guidelines in order to design key processes in the restaurant. In addition, an inquiry about the effects caused by the loss of customers in the restaurant due to the sanitary emergency caused by COVID-20I9. San Vicente in gastronomy stands out for its variety that combines dishes from the sea and inland; therefore, the present project was carried out in the restaurant Mi Galito which is located in the canton San Vicente and was conducted within the context of the pandemic. (Pacheco-Coral, 20I7, p. 27I)

The restaurant Mi Galito provides a service to the community, offering catering services having different types of dishes, closer to the place of work or residence, i.e., seeks the welfare of its customer effectively and aligned with their needs. The present project seeks to determine and design the sales processes, and also to cover the needs of local and national tourists visiting the city of San Vicente, and it is also expected to develop strategies based on the attention and quality service. In view of this, it is necessary to ask the following question: How does the design of organizational structures and alternative sales processes through the adoption of strategies and biosecurity measures impact the operations of the restaurant?

Through an investigation on the application of sales strategies in the Mi Galito restaurant in the canton of Sucre - Manabí, an organizational structure and administrative procedures manual will be designed to contribute to the sustainability of the establishment after the Covid-19 health emergency, in addition to proposing specific 
biosecurity measures based on the general provisions issued by the authorities for the safe reopening of food and beverage establishments. (Castell Monsalve et al., 2009, p. 562)

Due to the increase in the number of infected people in the city of San Vicente, it was decided to close the restaurant due to the health emergency and to avoid the contagion of both employers and customers, the paralysis of the restaurant resulted in a lack of liquidity, so it was decided to reduce the staff. Consequently, all this generated a loss of customers and a decrease in income, in the worst case, the closure of the business. (Carranza et al., 202I, p.8)

Given the constant calls to take social distancing, the correct use of masks and antiseptic alcohol, some people take it very lightly on the other hand there are those who enter into a state of mind sometimes depressive, or panic and in many cases stress, which indicates that many of us are reluctant to change.

As a result, businesses will not have the same number of people as before, so the different businesses, and one of the most interested in this are the restaurants, such as "Mi Galito", are opting for other measures in order to generate income and resume certain activities. (Manzano et al., 202I)

This work allowed to show the impact that has occurred and how it has declined at an accelerated economic level in the second quarter of 2020. In addition, to offer a solution, from the administrative perspective that allows the restaurant to improve its economic situation. We then proceeded to investigate the means of exit in order to have a better business management. Prior to this, a study was developed, in which effective results were obtained that promoted its economic development. For the owner, closing the establishment was a difficult decision since restaurants do not usually have a financial cushion, but they do it to raise awareness and avoid contagion.(Oportunidades Gastronómicas, 2020)

Organizational design can be understood as "the process by which we build or change the structure of an organization, in order to achieve the objectives we have in mind". (de la Calle-Prieto et al., 20 I8, p.520). Organizational design is one of the most important factors since it allows knowing all the procedures that have occurred within it, allowing the integration of people, providing information.

According to (Santos \& Regueiro, 202I) "The organizational structure is reflected in the organization chart. By organizational structure it is understood that it is the one in which organizations are organized, through this the goals and objectives to be met are set out, which are represented in their respective organizational charts" p.320. The main organizational structures are: divisional structure, geographical structure, matrix structure, horizontal structure and hybrid structure. It was imperative for this microbusiness to define its structure as the "blueprint" under which all relationships, functions, communications and coordination within the business take place. In this sense, for this restaurant, the functional structure was defined to encourage the specialization of functions since they operate in a more stable environment. 
Most companies combine the characteristics of functional, divisional, geographic, horizontal, and network structures to take advantage of the strengths of various structures and avoid some of the weaknesses (Zorrilla-Vaca \& Escandón-Vargas, 2017, p. 73)

As mentioned, this work was based on the functional structure. Since this is based on the fact that each employee has a superior and the teams are grouped by specialties; that is, it is vertically integrated from the bottom to the top of the organization. The mixed type organization chart was used, which is the result of the combination of several types of organization charts, with the objective of having a complex structure.

A procedures manual was created with the objective of establishing information and communication with greater understanding between the areas that make up the Mi Galito restaurant in order to efficiently comply with the purposes entrusted, as well as to improve the establishment through an administrative procedures manual through which both managers and employees know how to perform their work. Also, of other additional advantages. Likewise, to verify if the work processes are carried out correctly so that they meet the expectations of the clients. (Cuende et al., 202I, p. 376)

In addition, a biosecurity protocol was developed based on the specific norms according to each type of service in the restaurant sector; whether for the customer at the time of arrival or serving the food or for the person cooking the food. We wanted to know how the pandemic had affected businesses; it is also necessary to know this information since it is important to know the problems that are experienced on a daily basis.

For Chica-Meza et al., (2020) This project provides knowledge on either how to do or why a procedures manual is important in a business and the importance of the correct use of biosecurity protocols, as well as information on how this type of business is being managed in the context of the pandemic.

\section{MATERIALS AND METHODS}

Two types of research were used to carry out the research, which are the following: Exploratory research; this research is described because information was inquired for the elaboration of a survey of closed questions which was based on the customer's preference at the time of acquiring the product, likewise a general interview was conducted with the restaurant manager. On the other hand, the descriptive research; this research is introduced because it allowed to evaluate the characteristics of the business and the details about the service and product offered to the consumers.

With a deductive and inductive approach, in which the sales processes of the restaurant were analyzed, it was also examined what the function of each employee consists of; after examining the situation studied, it was decided to make organization charts that explain and discipline each operator about what their work consists of as a worker of the restaurant Mi Galito. Likewise, an analytical and synthetic approach was used since the work performed by each employee was monitored, and it was also analyzed how customer service is carried out by each one of them, in order to draw conclusions about the problems investigated. 
A survey was conducted with a sample of customers of the Mi Galito restaurant in the city of San Vicente, who responded to a series of questions contained in questionnaires, which were tabulated and interpreted in order to determine the degree of customer satisfaction.

As for the techniques, an interview was applied; where Mrs. Rosa Bolivia Rosales Ganchoso Manager and owner of the establishment was interviewed, in this criterion a semi-structured interview was used. In addition, a survey was conducted; the same that was made to 40 people through Google Forms that was sent to the restaurant customers with closed and multiple choice questions, this sample was selected from the operational point of view in the context of the pandemic, as the main characteristic to be surveyed was to be either regular or irregular customers of the restaurant. The age, physique, or ethnicity of respondents did not affect survey responses as long as they had visited the restaurant. Therefore, the probability sampling method was used, characterized by simple random sampling; used to collect information at critical moments such as the one experienced during the pandemic.

\section{RESULTS}

The application of the investigative techniques of interviewing the establishment's personnel and surveying its customers made it possible to obtain the following information on the establishment's current situation, which is presented below:

Through this interview, the owner learned how the arrival of the pandemic affected the establishment and how it is reactivating in the market, how many people were working before and after the pandemic, and how the home delivery service is being developed in order to increase sales. Due to the increasing number of infected people, people opted to stay at home, which generated a high decrease of customers to the establishment, so the restaurant Mi Galito applied the sales strategy "home delivery" which generates sales and helps the financial crisis, however the owner stresses that she is concerned that sales produced in the course of the pandemic do not generate sufficient income.

As a result of the research, a survey was conducted among the restaurant's customers to determine their level of satisfaction, taste, preference, quality, ambiance and product offered by the restaurant:

The main questions raised are presented below:

The customers' opinion about the taste of the food is very important. Since every customer has different tastes, Mi Galito restaurant has a variety of dishes to satisfy different tastes and flavors in order to please all its customers.

Thus, 35\% of the surveyed population mentioned that the taste of the food is very good; on the contrary, $55 \%$ of the respondents said that the food is good while $10 \%$ of the surveyed population said that it is average, however, no one said that the food served in the restaurant is bad.

This shows that the good taste of the restaurant's food is recognized because $90 \%$ of the respondents answered positively, so this study can be supported by this question. 
The target client segment for this type of service is office workers, workers in general, as well as university students from neighboring areas, and tourists. Due to the pandemic, it is necessary to have a special treatment with the clients since they have to follow the biosecurity measures.

Moreover, when asked how they feel about the service provided by the restaurant's employees, favorable responses can be observed; $100 \%$ of the population indicated that they were satisfied with the service provided, since $22 \%$ mentioned that they felt very satisfied while $78 \%$ said they felt satisfied.

This question is relevant, as it provides an insight into how the restaurant is viewed from the customers' perspective, as well as building customer loyalty.

In addition to knowing if the taste of the food is pleasant to customers. Figure ${ }^{\circ} 3$ clearly shows that $24 \%$ of the people surveyed mentioned that they visit the restaurant because of the price of the dishes; while $38 \%$ indicated that they visit it for pleasure; however, the other $38 \%$ mentioned that they visit the restaurant for its variety of flavors.

\section{-Digital marketing tools}

At present, Mi Galito restaurant has a home delivery service. This service was implemented in the establishment due to the arrival of Covid-19 in the country, which had a great impact on society and the business economy.

This service is performed by the call given by the customer, which is received by the restaurant representative who takes the order and gives way to the realization of the dish for proper delivery.

This strategy is very viable but it can fail if it does not have an adequate marketing strategy, so the decision was made to create a web page in "wix.com" a free page to create web sites with advertising included, its purpose is to constantly attract customers and increase sales since, due to the pandemic, sales dropped.

Therefore, it was suggested that the restaurant should have a website that would improve its cash inflow, thus giving it greater openness and an increase in clientele.

On the website https://migalitosanvicente.wixsite.com/ecuador you can find the exquisite dishes offered by the restaurant Mi Galito. There are also different ways to contact us to place your home delivery orders.

\section{-Biosafety protocol}

The biosafety protocol was implemented with infographics for easier understanding, since it has been proven that people are more visual and it is more effective for them to be guided and apply the images, with specific measures for this establishment, which guarantees the safety of customers and the people working in the establishment, as well as the continuity of the restaurant's activities, applying social distancing, home deliveries, among others.

\section{-Procedures manual}

The procedure manual:

"It serves as a means of communication and coordination to record and transmit in an orderly and systematic way the information of an organization also allows a better understanding of the development of routine activities at all hierarchical 
levels, which is conducive to the reduction of failures or omissions and increased productivity." (Díez et al., 2016, p.79)

Therefore, the procedures manual is a fundamental element in organizations.

Figure $\mathbf{N}^{\circ}$ I. Organizational structure (organization chart).

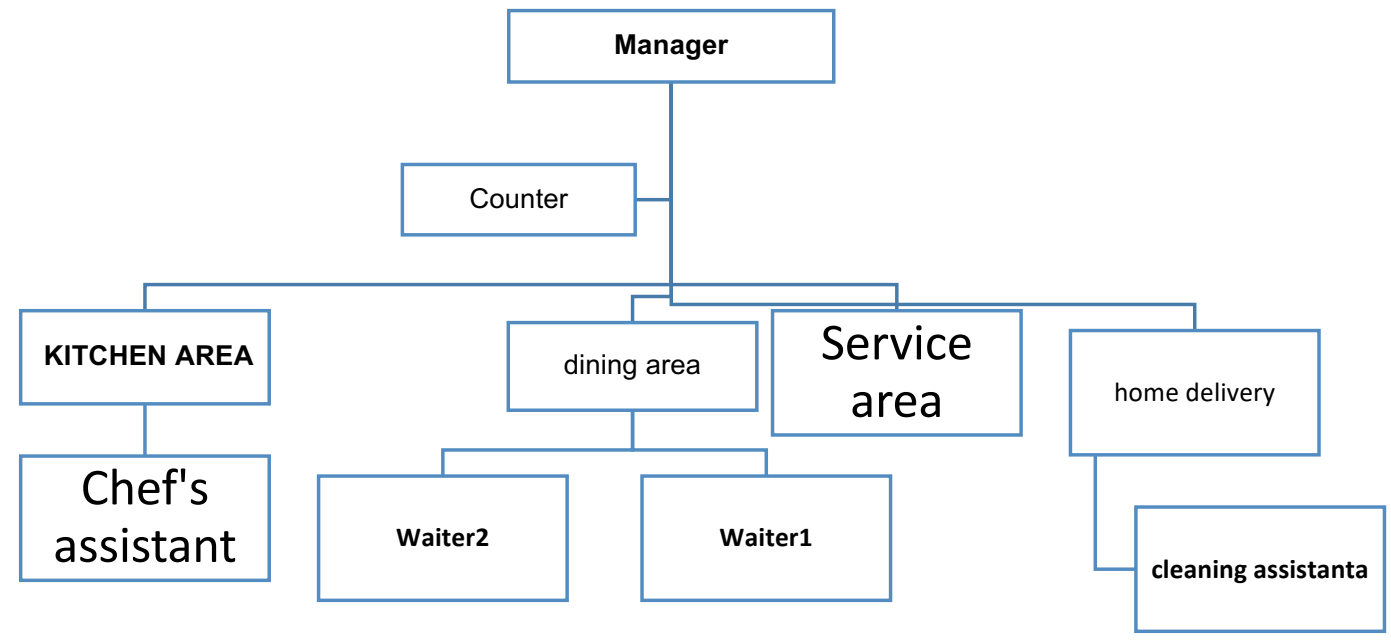

Designed in Microsoft Visio

Prepared by Pazmiño A.

As for the development of the procedure manual, it was necessary to know the different activities that were developed within the organization in order to create a strategy with the objective of optimizing the use of resources.

The proposed manual provides the organizational structure adapted to the new way of operating this micro business.

The manual provided to the facility includes flowcharts of the key processes:

Customer service, product purchasing, home delivery, food processing and product receiving. In addition, within the procedures manual there are the process flow diagrams, which are a graphic representation that breaks down a process in any type of activity. Carranza Esteban et al., (202I) are a graphic representation that breaks down a process into any type of activity and are of great importance since they help to designate any graphic representation of a procedure or part of it.

Four processes were taken into account:

I. Purchasing process, with a maximum duration of 3 hours, involving the establishment's manager, the accountant, the supplier and the assistant chef.

2. Another process was the preparation of the food, which lasted between 2 to 3 hours and involved the chef and the chef's assistant.

3. The Customer Service process was also taken into consideration, detailing step by step how to serve a customer while respecting biosafety measures; the process lasts 
from one and a half to two hours, since the waiter must be alert during the time the customer is served the food.

4. The last process that was developed was home delivery, which has a maximum duration of an hour and a half depending on the distance between the restaurant and the delivery place, in this process involves the customer, the cashier, the chef and the delivery person.

\section{-Budget}

Among the main reasons why many businesses, especially restaurants and the restaurant sector in particular, delay in reactivating their activities is the increase in costs, especially the allocation of costs for biosecurity equipment for personnel and equipment and supplies for customers. The investment required for this establishment, according to its capacity, is presented in the following tables:

Table $\mathbf{N}^{\circ}$ I Budget given to the new pandemic adaptation.

\begin{tabular}{|c|c|}
\hline VISIBLE LABELS: & VALUE \\
\hline No crowding of people & USD 8,00 \\
\hline Mandatory use of gloves & USD 8,00 \\
\hline Mandatory use of face masks & USD 8,00 \\
\hline Numbers to call in case of health emergency & USD 8,00 \\
\hline \multicolumn{2}{|l|}{ BOXES: } \\
\hline Cash basket & USD 5,00 \\
\hline \multicolumn{2}{|l|}{ UNIFORMS: } \\
\hline Uniforms/Work uniforms (pcs.) & USD 50.00 \\
\hline \multicolumn{2}{|l|}{ WASTE MANAGEMENT } \\
\hline pedal-operated containers & USD 35,00 \\
\hline \multicolumn{2}{|c|}{ GOGGLES, CARPET AND PISTOL TYPE THERMOMETER: } \\
\hline Pistol type thermometer & USD 20,00 \\
\hline Glasses or visors ( 8 pcs.) & USD 20,00 \\
\hline Disinfectant mat for footwear & USD 18,00 \\
\hline TOTAL & USD 160.00 \\
\hline
\end{tabular}

Table $\mathbf{N}^{\circ} 2$ Biosafety items and materials (monthly)

\begin{tabular}{ll}
\hline DISINFECTANTS, ALCOHOL AND SOAPS: & VALUE \\
\hline For hands, dishes and utensils & USD 50,00 \\
For floors, bathrooms and toilets & USD 50,00 \\
GLOVES, MASKS AND HAIR NETS: & \\
Disposable sanitary gloves & USD 25,00 \\
Protective hair netting & USD 10,00 \\
Disposable handkerchiefs and masks & USD 20,00 \\
WASTE MANAGEMENT: & \\
Bags for waste separation. & USD 5,00 \\
TOTAL MONTHLY & USD 160.00 \\
\hline
\end{tabular}


Covid-19 is one of the most deadly diseases that caused the paralysis of the whole world, this disease is too risky because it can bring people with a certain vulnerability deficit to the brink of death or in the worst cases cause death. In effect, people have chosen to take care of their health and not to leave their homes unless necessary. In this pandemic, micro-businesses decided to reconvert their businesses in different ways. The restaurant Mi galito offered home delivery service, so that customers can be safe at home and the restaurant can earn income while generating sales. Microbusinesses are forced to make changes to survive in the market in the face of contingencies. Therefore, adapting to the new sales strategy such as home delivery or providing biosecurity value to both internal and external customers are current challenges. Therefore, organizational theory helps to explain what happened in the past, as well as what might happen in the future, in order to manage organizations more effectively.

\section{CONCLUSIONS}

The adaptations of the new lifestyle and consumer behavior in the context of the pandemic marked changes in its organizational structure that negatively affected the establishment, given the research it is concluded that the restaurant "MI GALITO" does not have a well structured plan on sales and distribution processes, due to several factors, the first of which is that it does not have a manual that allows them to be prepared for any circumstances that may arise, consequently the misinformation by the owner and finally does not have a well-structured sales plan.

The restaurant has obtained an influx of customers because it provides a good service for which they are satisfied both in taste and in the price of meals, since the measures taken by other restaurants, is the increase in the price of the dishes and the reduction of ingredients for them.

On the other hand, it should be clarified that we were not prepared neither psychologically nor physically for the arrival of a pandemic which has affected the whole world not only economically but also the physical and mental health since it has a high mortality rate and even more the rate of virality that has this disease, which has taken us some time to adapt to it.

\section{REFERENCES}

Carranza, R. F., Mamani-Benito, O. J., Quinteros-Zúñiga, D., \& Farfán-Solís, R. (202I). Concern about COVID- 19 infection and workload as predictors of psychological distress during the health emergency in Peruvian healthcare personnel. Revista Colombiana de Psiquiatria, $x x$, I7. https://doi.org/I0.1016/j.rcp.2021.06.005

Castell, J., Gutiérrez, G., \& Ruiz, M. A. (2009). Three outbreaks of brucellosis investigated in one year of occupational health surveillance in Ciudad Real. Gaceta Sanitaria, 23(6), 562-563. https://doi.org/I0.1016/j.gaceta.2009.05.013.

Chaturvedi, K., Vishwakarma, D. K., \& Singh, N. (202I). COVID-I 9 and its impact on education, social life and mental health of students: A survey. Children and Youth Services Review, I2I, 105866. https://doi.org//0.1016/J.CHILDYOUTH.2020.105866. 
Chica-Meza, C., Peña-López, L. A., Villamarín-Guerrero, H. F., Moreno-Collazos, J. E., RodríguezCorredor, L. C., Lozano, W. M., \& Vargas-Ordoñez, M. P. (2020). Respiratory care in COVID-19. Acta Colombiana de Cuidado Intensivo, 20(2), 108-II7. https://doi.org//0.1016/j.acci.2020.04.00I.

Cuende, N., Álvarez-Márquez, A. J., Díaz-Aunión, C., Castro, P., Huet, J., \& Pérez-Villares, J. M. (202I). The regenerative medicine and stem cell business: confusion with legal implications. Gaceta Sanitaria, 35(4), 374-378. https://doi.org/10.1016/j.gaceta.2019.12.004

de la Calle-Prieto, F., Martín-Quirós, A., Trigo, E., Mora-Rillo, M., Arsuaga, M., Díaz-Menéndez, M., \& Arribas, J. R. (2018). Therapeutic management of Crimean-Congo haemorrhagic fever. Enfermedades Infecciosas y Microbiologia Clinica, 36(8), 517-522. https://doi.org/I0.1016/j.eimc.2017.04.007.

Díez, E., Aviñó, D., Paredes-Carbonell, J. J., Segura, J., Suárez, Ó., Gerez, M. D., Pérez, A., Daban, F., \& Camprubí, L. (2016). A good investment: health promotion in cities and neighborhoods. Gaceta Sanitaria, 30, 74-80. https://doi.org/I0.1016/j.gaceta.2016.04.015.

Manzano Aquiahuatl, C., Tobar Fredes, R., Zavala Solares, M. R., Salle Levy, D., Imamura, R., Morales Fernández, R., Ojeda Peña, L., Parra Reyes, D., Santoro, P., Ton, V., Trujillo Benavides, O. E., Vargas García, M., \& Furkim, A. (202I). Positioning of the Latin American Dysphagia Society for the management of oropharyngeal and esophageal dysphagia during the COVID-19 pandemic. Revista de Gastroenterología de México, xxxx. https://doi.org/I0.1016/j.rgmx.2021.08.002.

Gastronomic opportunities. (2020). Stone Mortar.

Pacheco-Coral, A. del P. (2017). Zika, Guillain-Barré and anesthesiology: a point of intersection between public health and clinical practice. Revista Colombiana de Anestesiologia, 45(4), 269 27I. https://doi.org/I0.1016/j.rca.2017.07.004.

Santos, G. G., \& Regueiro, B. P. (202I). Changes in dental care in primary care due to SARSCoV-2. FMC Formacion Medica Continuada En Atencion Primaria, 28(6), 318-323. https://doi.org//0.1016/j.fmc.2020.11.008

Zorrilla-Vaca, A., \& Escandón-Vargas, K. (2017). The importance of infectious disease control and prevention in anesthesiology. Revista Colombiana de Anestesiologia, 45(S 2), 69-77. https://doi.org//0.1016/j.rca.2017.09.002. 